\title{
Optimasi Asymmetric City Tour di Kota Kediri Menggunakan Ant Colony System
}

\section{(Asymmetric City Tour Optimization in Kediri Using Ant Colony System)}

\author{
Abidatul Izzah ${ }^{1}$, Benni A. Nugroho², Wayan F. Mahmudy ${ }^{3}$, Fitra A. Bachtiar ${ }^{4}$
}

\begin{abstract}
Kediri City is a stopover/transit city and has many potentials in the fields of tourism, education, and industry. Thus, the City of Kediri became one of the cities that are very likely to develop and be crowded. Therefore, it is required to model city tours in several primary fields of Kediri City. In the literature, determining the optimum route can be approached as a traveling salesman problem. However, traveling salesman problem model cannot be used to determine the city tour path as the distance among the point may vary. In this study, we used the concept of asymmetric traveling salesman problem to solve the city tour path. Furthermore, we used the ant colony system algorithm to solve this problem. The cases resolved in this study are the location of the tourism center, industrial center, and education center in Kediri City. The results show the ant colony system is capable of providing optimum tour route solutions, namely the city tourist route $34.65 \mathrm{~km}$, the industrial route $21.19 \mathrm{~km}$, and the school route $28 \mathrm{~km}$.
\end{abstract}

Intisari-Kota Kediri merupakan kota persinggahan lalu lintas transportasi dan memiliki sejumlah potensi di bidang pariwisata, pendidikan, dan industri. Dengan demikian, Kota Kediri menjadi salah satu kota yang sangat mungkin untuk berkembang dan ramai dikunjungi. Oleh karena itu, Kota Kediri dipandang perlu memodelkan city tour di beberapa bidang yang dapat diunggulkan. Jika ditilik dari disiplin ilmu komputasi, penentuan rute optimum dapat didekati sebagai permasalahan traveling salesman problem. Namun, model traveling salesman problem standar tidak dapat diimplementasikan pada kasus penentuan city tour karena jarak antar lokasi yang mungkin berbeda. Oleh karena itu, pada makalah ini, city tour diselesaikan menggunakan konsep asymmetric traveling salesman problem. Selanjutnya, algoritme an colony system diimplementasikan dalam penyelesaian masalah ini. Kasus yang diselesaikan pada makalah ini adalah lokasi pusat pariwisata, pusat industri, dan pusat pendidikan di Kota Kediri. Hasil yang diperoleh adalah ant colony system mampu memberikan solusi rute tur yang optimum, yakni rute tempat wisata kota 34,65 km, rute industri $21,19 \mathrm{~km}$, dan rute sekolah 28 km.

Kata Kunci-Asymmetric City Tour, Ant Colony System, Optimasi, Traveling Salesman Problem.

1,2 Manajemen Informatika,, PSDKU Politeknik Negeri Malang Kediri, Sukorame, Kec. Mojoroto, Kediri, Jawa Timur 64119 INDONESIA (Tlp: +62-354-683128; e-mail: abidatul.izzah90@gmail.com)

${ }^{3,4}$ Fakultas Ilmu Komputer, Universitas Brawijaya, Veteran Malang, Ketawanggede, Kec. Lowokwaru, Kota Malang, Jawa Timur 65145 INDONESIA (Tlp: +62-341-577911)

\section{Pendahuluan}

Kota Kediri merupakan kota persinggahan lalu lintas transportasi dan memiliki sejumlah potensi di bidang pariwisata, pendidikan, dan industri. Kota ini terletak $130 \mathrm{~km}$ sebelah barat daya Surabaya dan merupakan kota terbesar ketiga di Jawa Timur setelah Surabaya dan Malang, berdasarkan jumlah penduduk. Kota Kediri memiliki luas wilayah $63,40 \mathrm{~km}^{2}$ dan seluruh wilayahnya berbatasan dengan Kabupaten Kediri. Pada tahun 2017, Kota Kediri memperoleh Penghargaan Smart City [1]. Melihat kondisi tersebut, Kota Kediri menjadi salah satu kota yang sangat mungkin untuk berkembang dan ramai dikunjungi. Oleh karena itu, Kota Kediri dipandang perlu untuk memodelkan city tour di beberapa bidang yang dapat diunggulkan, antara lain pendidikan, industri, dan pariwisata, untuk membantu upaya pemerintah kota dalam pemberdayaan kota secara menyeluruh.

Jika ditilik dari disiplin ilmu komputasi, penentuan rute city tour optimal dapat didekati sebagai permasalahan Traveling Salesman Problem (TSP). TSP termasuk kategori NP-Hard Problem yang merupakan sebuah permasalahan yang sulit dipecahkan secara analitis, sehingga terdapat banyak variasi metode yang dapat digunakan. Persoalan yang dihadapi ialah cara membangun rute yang optimum dengan mempertimbangkan aturan pada TSP, yaitu melewati setiap lokasi selain lokasi awal hanya satu kali, dengan tujuan mendapatkan total jarak tempuh minimal, sehingga berdampak pada penghematan biaya transportasi. Secara analitis, permasalahan TSP merupakan permasalahan yang sulit dipecahkan karena terdapat banyak kombinasi alur rute yang mungkin terjadi seiring dengan banyaknya kota yang akan dikunjungi dan juga harus memperhatikan aturan yang berlaku [2]. Namun, model TSP standar tidak dapat diimplementasikan pada penentuan city tour karena jarak antar lokasi mungkin berbeda. Kasus seperti ini disebut dengan asymmetric traveling salesman problem (ATSP), yakni kasus TSP yang setiap arahnya berlawanan dan direpresentasikan dengan graph tidak terarah. Hal ini sesuai dengan fakta di lapangan bahwa lokasi di Kediri dihubungkan oleh jalur yang mungkin tidak ada di kedua arah atau jarak mungkin berbeda dan membentuk graph yang tidak berarah [3].

Banyaknya kasus TSP telah diselesaikan baik untuk menyelesaikan kasus secara nyata [3] maupun dalam penelitian pengembangan metode komputasi [4], [5]. Banyaknya penelitian yang telah dilakukan menyebabkan beragam pula metode penyelesaian yang telah digunakan. Salah satu metode yang sering digunakan untuk menyelesaikan masalah NP-Hard 


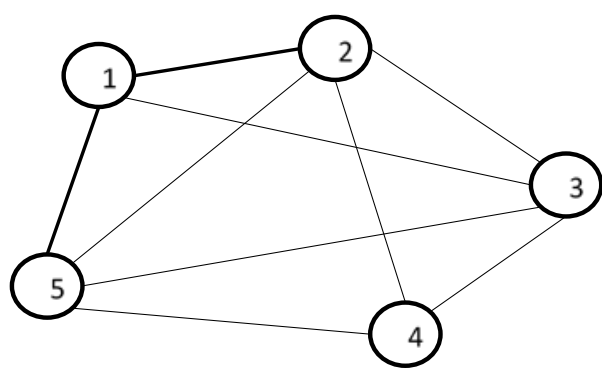

Gbr. 1 Graph reprentasi traveling salesman problem.

adalah genetic algorithm, Particle Swarm Optimization (PSO), dan ant colony system (ACS) [4]-[10]. Lebih lanjut, ditunjukkan bahwa telah dilakukan penelitian dengan membandingkan beberapa metode untuk kasus pencarian rute ACS yang memberi hasil yang baik dari segi efektivitas waktu dan cost penentuan jarak rute dibandingkan dengan metode yang lainnya [6]. Oleh karena itu, pada makalah ini, ACS digunakan sebagai metode untuk menentukan rute terpendek city tour di kota Kediri.

Dengan demikian, makalah ini menyelesaikan permasalahan penentuan rute city tour di Kota Kediri untuk lokasi wisata kota, industri dan pendidikan menggunakan metode ACS berbasis model ATSP secara riil. Sistematika penulisan yang digunakan dalam makalah ini diawali dengan studi pustaka tentang ATSP dan ACS. Selanjutnya, dilakukan proses pengambilan data lokasi virtual yang kemudian disimpan dalam matriks adjecancy. Selanjutnya, ACS diimplementasikan dan dievaluasi kinerjanya sehingga diperoleh hasil city tour yang optimum dan meng-hubungkan lokasi-lokasi tersebut. Kinerja yang dievaluasi antara lain optimasi berdasarkan jarak tempuh dan titik konvergensi algoritme.

\section{ASYMMETRIC CITY TOUR}

TSP adalah sebuah kasus combinatory yang menggambarkan seorang salesman harus mendatangi seluruh titik kota yang telah ditentukan dan diharuskan tiap titik kota hanya bisa didatangi sekali, dengan ketentuan salesman harus memulai dari dan berakhir ke kota asal. Tujuan dari permasalahan TSP ini adalah menentukan rute dengan jarak total atau biaya yang paling optimum [11]. Kasus TSP dapat direpresentasikan dalam graph komplet tidak berarah seperti yang ditunjukkan pada Gbr. 1.

Contoh pada Gbr. 1 adalah graph yang terdiri atas lima node dengan antar node memiliki bobot. Node pada graph tersebut menggambarkan titik-titik lokasi dan bobot antar node dapat meggambarkan jarak, waktu, atau cost antar lokasi. Lebih lanjut, jika $i$ dan $j$ merepresentasikan lokasi dan $d_{i j}$ merupakan jarak antara $i$ dan $j$, maka secara matematis, model graph tersebut dapat disusun dalam matriks adjacency simetris $\left(d_{i j}=d_{i j}\right)$ sebagai berikut.

$$
D=\left[\begin{array}{ccccc}
d_{11} & d_{12} & d_{13} & \ldots & d_{1 n} \\
d_{21} & d_{22} & d_{23} & \ldots & d_{2 n} \\
d_{31} & d_{32} & d_{33} & \ldots & d_{3 n} \\
\ldots & \ldots & \ldots & \ddots & \vdots \\
d_{n 1} & d_{n 2} & d_{n 3} & \ldots & d_{n n}
\end{array}\right]
$$

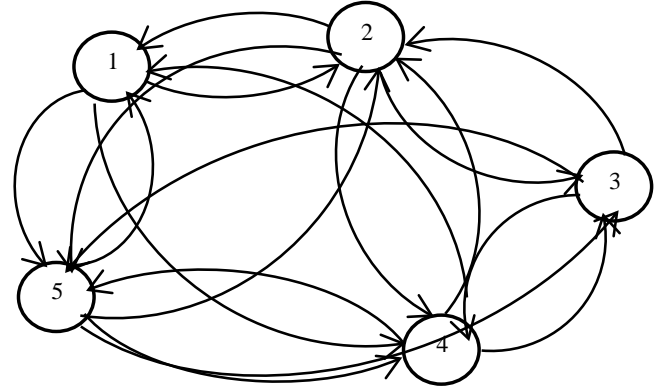

Gbr. 2 Graph representasi asymmetric traveling salesman problem.

Selanjutnya, didefinisikan variabel keputusan $x_{i j}$ yang merepresentasikan ada tidaknya perjalanan dari titik $i$ ke $j$ dalam suatu rute adalah sebagai berikut.

$$
x_{i j}= \begin{cases}1, & \text { jika ada perjalanan kendaraan dari } i \text { ke } j \\ 0, & \text { jika tidak ada perjalanan kendaraan dari } i \text { ke } j\end{cases}
$$

kemudian jika $Z$ merupakan fungsi tujuan TSP, dan $i, j=$ $1,2,3, \ldots, N$ maka fungsi tujuan $Z$ dirumuskan dengan meminimumkan

$$
Z=\sum_{i=1}^{n} \sum_{j=1}^{n} d_{i j} x_{i j}
$$

dengan batasan kendala

$$
\sum_{i=1}^{n} \sum_{j=1}^{n} x_{i j}=1, x_{i j}=0 \text { atau } 1
$$

Lebih lanjut, kasus TSP tidak dapat diimplementasikan secara langsung pada beberapa kasus, karena pada faktanya jarak antar lokasi tidak selalu sama $\left(d_{i j} \neq d_{i j}\right)$. Keadaan demikian disebut dengan ATSP. Jika TSP standar direpresentasikan dengan graph komplet tidak berarah, sebaliknya, ATSP dapat direpresentasikan menggunakan graph berarah seperti ditunjukkan pada Gbr. 2.

Secara matematis, dapat dituliskan bahwa jika himpunan titik dari graph $K$ dinotasikan dengan $V(K)$, bobot arah antara $i$ dan $j$ dinotasikan dengan $d_{i j}, P$ adalah sebuah path yang tersusun dari semua titik $\left(v_{1}, v_{2}, \ldots, v_{n}\right)$, panjang sikel (tur) $C$ adalah jumlah jalur di $C(P)$, maka ATSP adalah graph komplet berbobot $K$ yang terdiri atas $N$ titik dan terdapat tur Hamiltonian $H$ dari graph $K$ dengan meminimumkan bobot yang ada [3].

\section{ANT COLONY SYSTEM (ACS)}

Metode ACS merupakan metode optimasi yang diilhami dari mekanisme perilaku semut untuk mencari sumber makanan. Fakta di alam bahwa semut mampu menemukan jalur terpendek dari sumber kaki ke sarang tanpa memberi isyarat visual pada semut lain disebut komunikasi stigmergic. Untuk memberikan sebuah isyarat tersebut, semut menyimpan sejumlah zat kimia yang disebut feromon dan akan ditinggalkan di tanah saat berjalan mencari rute menuju sumber makanan. Feromon ini bertindak sebagai pengawetan memori semut untuk menghasilkan jalur terpendek, sehingga berguna untuk meningkatkan kemungkinan semut lain mengikuti jalur yang sama yang telah ditinggali feromon oleh semut sebelumnya. 
Semakin banyak semut berjalan di setapak jalan, maka semakin banyak feromon yang disimpan di jalan tersebut. Hal ini menyebabkan semakin banyak pula semut yang akan mengikuti jejak jalan setapak tersebut. Melalui mekanisme inilah semut memiliki kecerdasan untuk menemukan jalur terpendek [8].

Perilaku unik semut yang telah diuraikan di atas disusun menjadi sebuah algoritme ACS. Aspek penting dalam algoritme adalah adanya aturan transisi status (state transition rule) yang memberikan keseimbangan antara eksplorasi bobot dan bobot sebelumnya. Selanjutnya adalah adanya proses update feromon lokal yang diterapkan saat seekor semut menyusun sebuah solusi. Dan ketiga adalah adanya update feromon global yang diterapkan pada solusi tur terbaik [8].

Dari ketiga aspek kunci algoritme tersebut, ACS dimulai dengan menyebarkan semut pada seluruh node dan berpindah berdasarkan (3).

$s=\left\{\begin{array}{l}\arg \max _{u \in j_{k}(r)}\left\{\left[\tau(r, u)^{\alpha}\right],\left[\eta(r, u)^{\beta}\right]\right\}, \text { jika } q<q_{0} \\ S \quad \text {,yang lain }\end{array}\right.$

dengan $\tau$ adalah feromon, $\eta=1 / d$ adalah invers dari $d(r, s)$, $j_{k}(r)$ adalah himpunan node yang belum dikunjungi oleh $k$ semut yang ada di sedang berada di node $r, \beta$ adalah parameter yang menentukan perbandingan kepadatan feromon dengan jarak, $q$ adalah bilangan random $[0,1], q_{0}$ adalah parameter perbandingan ekploitasi dan eksplorasi, dan $S$ adalah node yang akan dikunjungi selanjutnya. Untuk mengunjungi node selanjutnya, semut berpindah berdasarkan (4).

$$
P_{k}(r, s)= \begin{cases}\frac{[\tau(r, s)]^{\alpha} \cdot[\eta(r, s)]^{\beta}}{\sum_{u \in j_{k}(r)}[\tau(r, s)]^{\alpha} \cdot[\eta(r, u)]^{\beta}}, & \text { jika } s \in j_{k}(r) \\ 0 & \text {,yang lain }\end{cases}
$$

Selanjutnya, setelah seekor semut selesai membuat tur, algoritme memodifikasi atau menguapkan level feromon lokal menggunakan persamaan update feromon sebagai berikut.

$$
\tau(r, s) \leftarrow(1-p) \cdot \tau(r, s)+p \Delta \tau_{0}
$$

dengan

$$
\Delta \tau_{0}=1 / L_{m n} . N
$$

dengan $L_{m n}$ adalah panjang tur dari tetangga terdekat dan $N$ adalah jumlah total node.

Setelah semua semut selesai membangun tur, dipilih semut terbaik yang menghasilkan tur terpendek dari awal untuk melakukan update feromon global menggunakan (6).

$$
\tau(r, s) \leftarrow(1-p) \cdot \tau(r, s)+p \Delta \tau(r, s)
$$

dengan

$$
\Delta \tau(r, s)=\left\{\begin{array}{cc}
\frac{1}{L_{g b}}, & \text { if }(r, s) \in \text { tur terbaik } \\
0, & \text { untuk yang lain }
\end{array}\right.
$$

dengan $L_{g b}$ adalah panjang tur terbaik selama iterasi berjalan. Selanjutnya, secara ringkas algoritme ACS dapat ditulis sebagai berikut.
TABEL I

DAFTAR TAMAN KOTA DI KEDIRI

\begin{tabular}{|l|c|c|}
\hline \multirow{2}{*}{\multicolumn{1}{|c|}{ Nama }} & \multicolumn{2}{c|}{ Lokasi } \\
\cline { 2 - 3 } & Latitude & Longitude \\
\hline Taman Sekartaji & $-7,81039$ & 112,004 \\
\hline Taman Ngronggo & $-7,83844$ & 112,011 \\
\hline Taman Harmoni Kediri & $-7,81232$ & 112,006 \\
\hline Taman Kota & $-7,81745$ & 112,027 \\
\hline Taman Brantas & $-7,81228$ & 112,008 \\
\hline Taman Wisata Tirtoyoso & $-7,81623$ & 112,029 \\
\hline Taman Bahagia & $-7,82224$ & 112,022 \\
\hline Taman Kresek & $-7,84017$ & 112,064 \\
\hline Taman Wisata Pagora & $-7,81608$ & 112,031 \\
\hline Taman Bunga Matahari & $-7,80943$ & 111,975 \\
\hline Taman Apartemen Rakyat & $-7,80558$ & 112,018 \\
\hline Surya Taman Wisata & $-7,83632$ & 112,056 \\
\hline Taman Unit Halim PT & $-7,79758$ & 112,027 \\
Gudang Garam Tbk & $-7,81231$ & 112,060 \\
\hline SLG Green Garden & \multicolumn{2}{|}{} \\
\hline
\end{tabular}

Inisialisasi: Set feromon semut awal untuk seluruh node dan matriks jarak antar node Loop /*perulangan untuk iterasi*/

Untuk setiap semut di node awal

Loop /*perulangan untuk step*/

Setiap semut melakukan state transition rule untuk mengusun solusi Update feromon local

Untill seluruh semut selesai membuat solusi

Update feromon global

Untill kondisi selesai

\section{Metodologi}

\section{A. Pengumpulan Data}

Data yang digunakan dalam makalah ini adalah data lokasi pusat pariwisata, pendidikan, dan industri di Kota Kediri. Data yang diambil berupa titik koordinat latitude dan longitude serta jarak antar node lokasi tersebut. Data diambil secara virtual menggunakan layanan peta Google (Google Map). Berikut ini contoh url yang digunakan untuk mengambil data lokasi wisata. Untuk mencari lokasi yang lain, maka query dapat disesuaikan dengan pencarian yang diinginkan.

\section{https://maps.googleapis.com/maps/api/pla

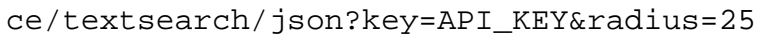 ๑००\&query=tempat+wisata}

Dalam pengumpulan sampel data pusat pariwisata, Google menunjukkan taman kota sebagai tempat wisata kota. Dari pencarian ini, ditemukan sampel lokasi sebanyak empat belas titik, seperti yang ditunjukkan pada Tabel I. Kemudian, dalam pengumpulan data lokasi pusat industri, ditemukan sampel sebesar empat belas titik seperti yang ditunjukkan pada Tabel II. Pengumpulan data dilanjutkan untuk kategori pusat pendidikan. Pusat pendidikan dapat berupa sekolah, kampus, lembaga kursus, dan lain-lain. Dari proses pencarian ini, ditemukan sampel lokasi sebanyak empat belas titik sekolah menengah atas seperti yang ditunjukkan pada Tabel III.

Selanjutnya, untuk menentukan city tour diperlukan jarak antar titik. Data jarak yang terkumpul kemudian disusun dalam 
TABEL II

DAFTAR INDUSTRI DI KEDIRI

\begin{tabular}{|l|c|c|}
\hline \multirow{2}{*}{\multicolumn{1}{|c|}{ Nama }} & \multicolumn{2}{c|}{ Lokasi } \\
\cline { 2 - 3 } & Latitude & Longitude \\
\hline PT Mandala Finance & $-7,80442$ & 112,00857 \\
\hline PT Gudang Garam Unit 1 & $-7,80481$ & 112,00975 \\
\hline PT Bhineka Life Indonesia & $-7,81148$ & 112,01678 \\
\hline PT Keong Nusantara Abadi & $-7,81420$ & 112,01130 \\
\hline PT Adira Dinamika Multi & $-7,81574$ & 112,02246 \\
Finance & $-7,81764$ & 112,02828 \\
\hline PT Sumber Sari Petung & $-7,80774$ & 112,03293 \\
\hline PT Oto Kredit Mobil & $-7,80482$ & 112,03448 \\
\hline PT Coca Cola Distributor & $-7,79721$ & 112,02554 \\
\hline PT Mekar Karya Nugraha & $-7,79732$ & 112,02338 \\
\hline PT Alam Tirta Plast & $-7,79558$ & 112,02197 \\
\hline PT Indomarco Adi Prima & $-7,79489$ & 112,01693 \\
\hline PT Wonojati Wijoyo & $-7,80454$ & 112,01077 \\
\hline PT Aglies Jaya Record & $-7,76658$ & 111,98000 \\
\hline PT Triples Group & & \\
\hline
\end{tabular}

TABEL III

DAFTAR SEKOLAH MENENGAH DI KEDIRI

\begin{tabular}{|l|c|c|}
\hline \multirow{2}{*}{ Nama } & \multicolumn{2}{c|}{ Lokasi } \\
\cline { 2 - 3 } & Latitude & Longitude \\
\hline SMAN 1 Kediri & $-7,81122$ & 112,00288 \\
\hline SMAN 2 Kediri & $-7,81134$ & 111,99920 \\
\hline SMAN 3 Kediri & $-7,83196$ & 112,04413 \\
\hline SMAN 4 Kediri & $-7,85435$ & 112,00699 \\
\hline SMAN 5 Kediri & $-7,80993$ & 111,97995 \\
\hline SMAN 6 Kediri & $-7,85318$ & 112,02202 \\
\hline SMAN 7 Kediri & $-7,81367$ & 112,00037 \\
\hline SMAN 8 Kediri & $-7,81655$ & 112,02803 \\
\hline SMKN 1 Kediri & $-7,81171$ & 111,99742 \\
\hline SMKN 2 Kediri & $-7,81125$ & 112,00031 \\
\hline SMKN 3 Kediri & $-7,81223$ & 112,01790 \\
\hline SMK PGRI 1 Kediri & $-7,81338$ & 111,99352 \\
\hline SMK PGRI 2 Kediri & $-7,81979$ & 111,99728 \\
\hline SMK PGRI 4 Kediri & $-7,80378$ & 112,00550 \\
\hline
\end{tabular}

matriks adjacency asimetris untuk ditentukan rute city tour. Oleh karena itu, pengumpulan data dilanjutkan dengan mengambil data jarak menggunakan url seperti berikut ini.

\$ $\{$ url $\}$ origin=\$ $\{$ list.get $(i)$. lat $\}, \$\{$ list.get ( i) . lng $\} \&$ mode=driving\&destination=place_id:\$ \{list.get $(j) \cdot$ placeId $\}$

\section{B. Penerapan Ant Colony System}

Setelah data terkumpul, tahapan selanjutnya adalah menerapkan algoritme ACS terhadap data tersebut. Berdasarkan pseudocode yang telah dituliskan sebelumnya, berikut adalah tahapan ACS dalam menyelesaikan kasus ATSP [7].

1. Pertama, menentukan parameter-parameter awal algoritme, yaitu $\alpha, \beta, \rho, \tau_{0}=\tau_{i j}$, dan $Q$.

2. Kedua, menghitung jarak antar node dan menghitung visibilitas antar node.

3. Ketiga, menyebarkan semut pada tiap node secara acak. Posisi awal semut pada node pertama ini merupakan posisi pertama tabu list tiap semut.
TABEL IV

Nilai DARI PARAMETER ANT COLONY SYSTEM

\begin{tabular}{|c|c|}
\hline Parameter & Nilai \\
\hline$\alpha$ & 1 \\
\hline$\beta$ & 1 \\
\hline$\rho$ & 0,05 \\
\hline$Q$ & 1 \\
\hline Jumlah semut & $10-50$ \\
\hline Jumlah iterasi & $100-300$ \\
\hline
\end{tabular}

4. Keempat, mengunjungi node lain yang belum ada pada tabu list berdasarkan aturan random proportional rule pada (4). Node dengan probabilitas terbesar merupakan node yang akan dikunjungi. Kemudian kunjungan tersebut diisikan pada tabu list.

5. Kelima, setelah semua semut mengunjungi seluruh node dan masing-masing tabu list semut penuh, panjang tur dari node pada tabu list masing-masing semut dihitung.

6. Keenam, melakukan proses update feromon lokal (5) dan mengosongkan tabu list masing-masing semut.

7. Ketujuh, mengulang proses ketiga sampai proses keenam dengan menggunakan feromon hasil update sebagai feromon awal. Proses ini juga dapat berhenti jika NCmax sudah terpenuhi.

\section{HASIL DAN PEMBaHASAN}

Pengujian dilakukan, untuk menentukan rute city tour optimum untuk tiga kategori lokasi tersebut, menggunakan algoritme ACS dengan variasi parameter berbeda. Parameter yang digunakan diperlihatkan pada Tabel IV.

Nilai yang dievaluasi untuk pengujian ini adalah nilai jarak tempuh yang optimum dan meninjau hasil kinerja ASC pada titik konvergensi dan waktu komputasi yang dibutuhkan.

\section{A. Hasil Pengujian Jarak Tempuh}

Uji coba dilakukan dengan mulai menerapkan algoritme ACS untuk menentukan rute city tour pusat pariwisata dengan empat belas titik lokasi. Pengujian dilakukan dengan memodifikasi jumlah semut dan iterasi. Perhitungan telah dilakukan sebanyak sepuluh kali untuk masing-masing parameter yang sama. Pengujian tersebut kemudian dirata-rata dan dibandingkan dengan parameter lain. Hasil dari pengujian ini ditunjukkan pada Gbr. 3. Dari hasil pengujian ini, nilai optimum sebesar 34,65 km sudah diperoleh bahkan ketika jumlah semut $=30$ dan maksimum iterasi $=100$. Nilai ini kemudian ditunjukkan kembali dan mendominasi solusi ketika jumlah semut $=50$ dan maksimum iterasi $=300$. Selanjutnya, dilakukan uji varians hasil rute dan menghasilkan bahwa varians yang ditunjukkan oleh masing-masing parameter tidak memiliki perbedaan yang signifikan. Hal ini yang menyebabkan hasil implementasi dalam grafik 3D yang ditunjukkan pada Gbr. 3 terlihat menurun untuk pertambahan jumlah semut dan iterasi, tetapi penurunan ini tidak bersifat curam.

Uji coba selanjutnya dilakukan dengan menerapkan algoritme ACS untuk menentukan rute city tour pusat industri dengan empat belas titik lokasi. Pengujian juga dilakukan dengan memodifikasi jumlah semut dan iterasi. Perhitungan telah dilakukan sebanyak sepuluh kali untuk masing-masing 


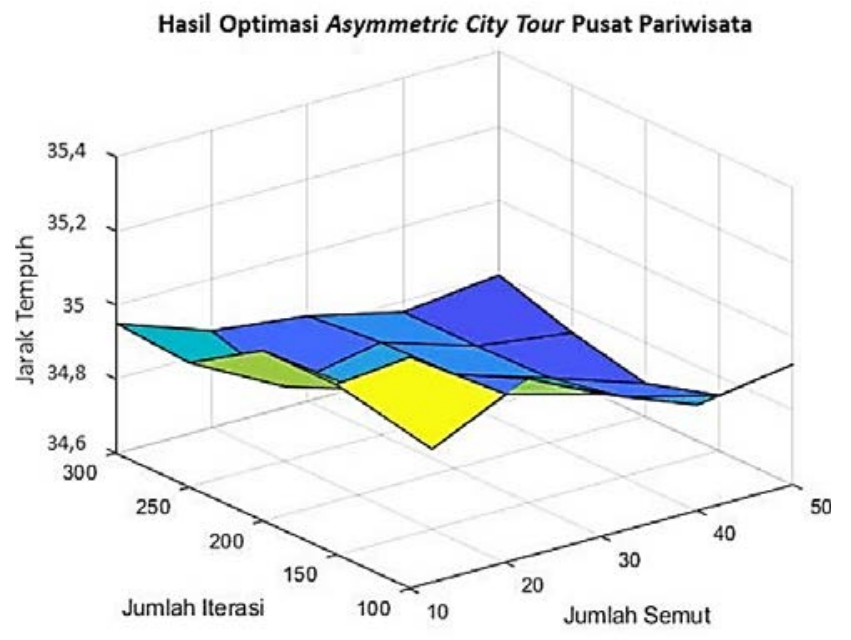

Gbr. 3 Hasil optimasi asymmetric city tour pusat pariwisata di Kediri.

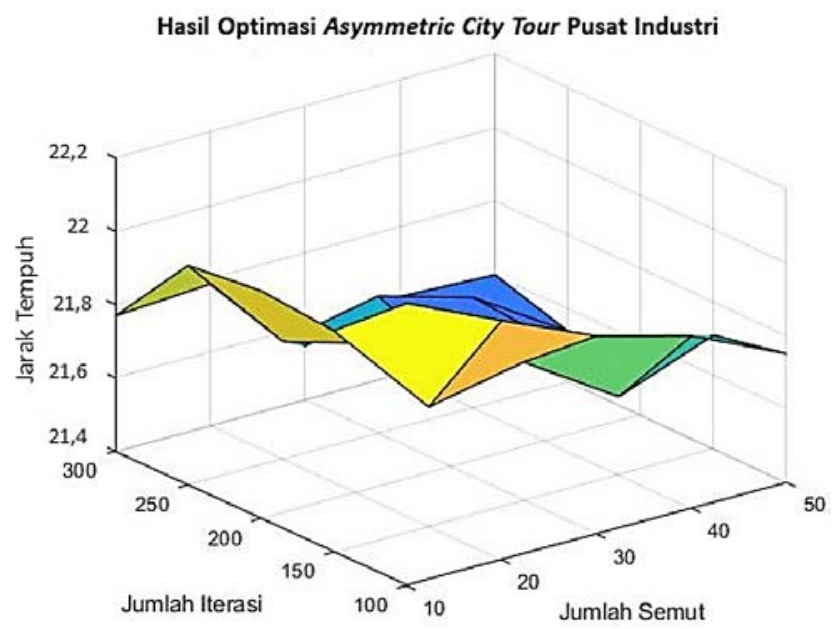

Gbr. 4 Hasil optimasi asymmetric city tour pusat industri di Kediri.

parameter yang sama. Pengujian tersebut kemudian dirata-rata dan dibandingkan dengan parameter lain. Hasil dari pengujian ini ditunjukkan pada Gbr. 4. Dari hasil pengujian ini, diperoleh nilai optimum sebesar 21,19 km. Nilai ini kemudian ditunjukkan kembali dan mendominasi seiring bertambahnya jumlah semut dan maksimum iterasi. Selanjutnya, dilakukan uji varians hasil rute dan menghasilkan bahwa varians yang ditunjukkan dari masing-masing parameter memiliki selisih yang lebih besar daripada percobaan pada kasus sebelumnya. Hal ini yang menyebabkan hasil implementasi dalam grafik 3D yang ditunjukkan pada Gbr. 4 lebih terlihat menurun dan curam untuk pertambahan jumlah semut dan iterasi.

Uji coba terakhir dilakukan dengan mulai menerapkan algoritme ACS untuk menentukan rute city tour pusat pendidikan dengan empat belas titik lokasi. Skenario pengujian juga seperti yang dilakukan sebelumnya, yakni dengan memodifikasi jumlah semut dan iterasi serta dilakukan sebanyak sepuluh kali untuk masing-masing parameter yang sama. Hasil dari pengujian ini ditunjukkan pada Gbr. 5. Dari hasil pengujian ini, nilai optimum sebesar $28 \mathrm{~km}$ sudah diperoleh bahkan ketika jumlah semut $=10$ dan maksimum iterasi $=100$. Sama seperti pada pengujian pertama, nilai ini

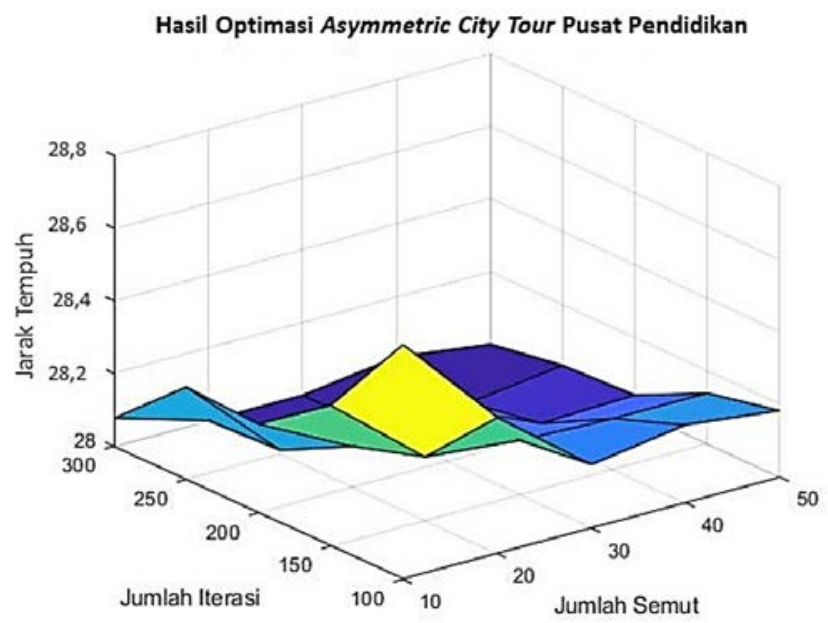

Gbr. 5 Hasil optimasi asymmetric city tour pusat pendidikan di Kediri.

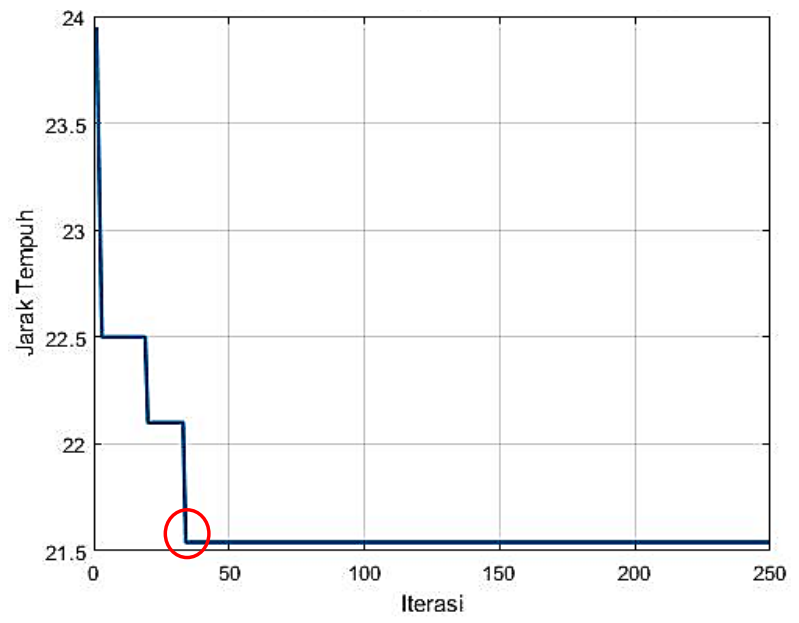

Gbr. 6 Kondisi konvergen.

kemudian ditunjukkan kembali dan mendominasi solusi ketika jumlah semut $=50$ dan maksimum iterasi $=300$. Setelah dilakukan uji varians untuk masing-masing parameter, hasil yang ditunjukkan pun sama dengan pengujian pertama, yakni varians dari hasil pengujian antar parameter memiliki selisih yang kecil. Hal ini yang menyebabkan hasil implementasi pada Gbr. 5 terjadi penurunan untuk pertambahan jumlah semut dan iterasi, tetapi tidak bersifat curam seperti pada Gbr. 3.

\section{B. Hasil Kinerja Ant Colony System untuk Menyelesaikan Asymmetric City Tour}

Selanjutnya, uji coba ditinjau dari keadaan berhentinya proses iterasi di suatu titik atau keadaan solusi tersebut tidak berubah sama sekali. Keadaan ini kemudian disebut dengan titik konvergensi (convergent point). Titik konvergensi ini terjadi ketika dalam satu swarm seluruh solusi memiliki nilai yang sama, dengan demikian lintasan semut tersebut tidak akan dapat berubah untuk setiap isi dari tabu list. Kondisi konvergensi seperti ini dapat dilihat seperti pada Gbr. 6.

Titik konvergensi seperti yang ditunjukkan pada Gbr. 6 dapat membuat kondisi komputasi ini menemukan solusi lebih cepat, tetapi dapat pula membuat kondisi ini tidak menemukan solusi global. Uji coba untuk mengetahui kondisi titik 


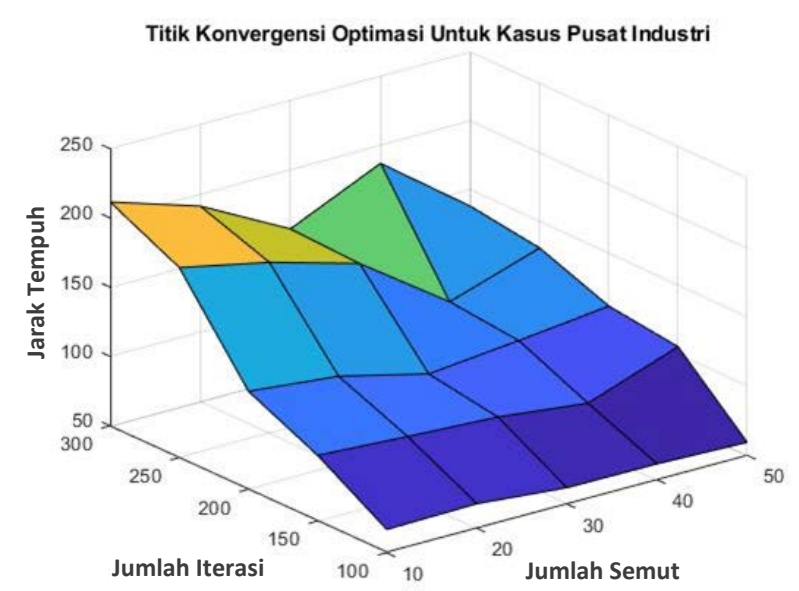

(a)

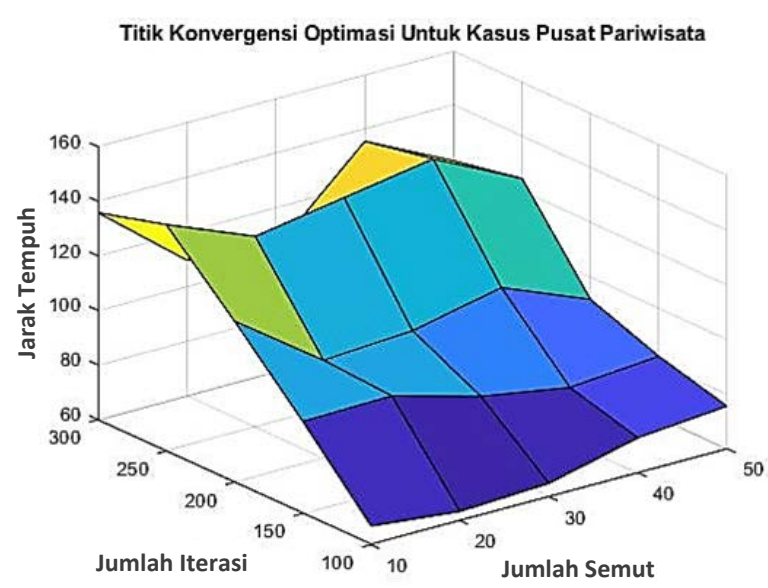

(b)

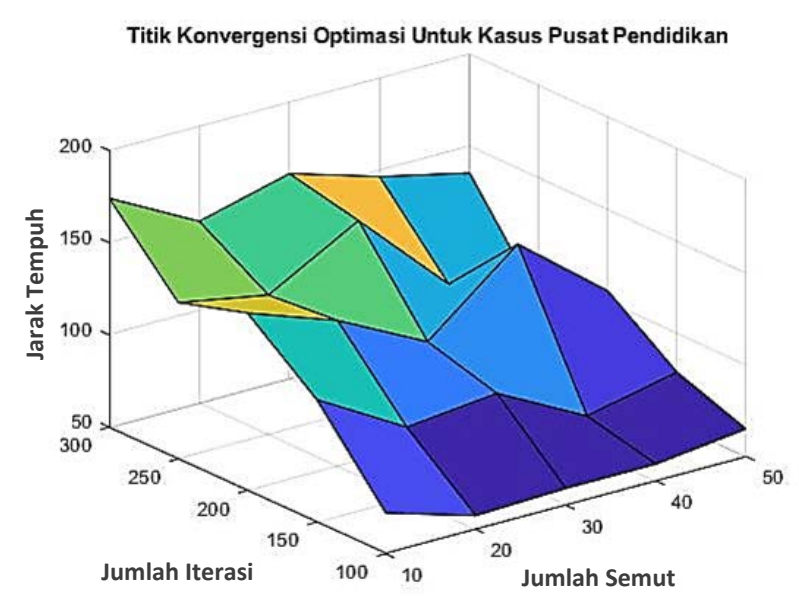

(c)

Gbr. 7 Hasil pengujian titik konvergensi.

konvergensi telah dilakukan dengan skenario yang sama untuk penentuan jarak tempuh city tour sebelumnya. Hasil perekaman titik konvergensi ditunjukkan pada Gbr. 7.

Pada Gbr. 7 terdapat kecenderungan yang sama, yaitu semakin bertambahnya jumlah iterasi, semakin bertambah pula
TABEL V

HASIL OPTIMASI KASUS ASYMMETRIC CITY TOUR DI KEDIRI

\begin{tabular}{|c|c|c|c|}
\hline \multirow[b]{2}{*}{ Jenis Tur } & \multicolumn{3}{|c|}{ Hasil Implementasi ACS } \\
\hline & Rute & $\begin{array}{c}\text { Jarak } \\
\text { Tempuh }\end{array}$ & $\begin{array}{c}\text { Waktu } \\
\text { Kompu- } \\
\text { tasi }\end{array}$ \\
\hline $\begin{array}{l}\text { Rute tempat } \\
\text { wisata kota }\end{array}$ & $\begin{array}{l}6 \rightarrow 9 \rightarrow 4 \rightarrow 7 \rightarrow 2 \rightarrow \\
3 \rightarrow 5 \rightarrow 1 \rightarrow 10 \rightarrow 13 \\
\rightarrow 11 \rightarrow 14 \rightarrow 12 \rightarrow 8\end{array}$ & $34,65 \mathrm{~km}$ & $0,543 \mathrm{~s}$ \\
\hline $\begin{array}{l}\text { Rute } \\
\text { industri }\end{array}$ & $\begin{array}{l}13 \rightarrow 3 \rightarrow 7 \rightarrow 1 \rightarrow 5 \rightarrow \\
10 \rightarrow 14 \rightarrow 2 \rightarrow 9 \rightarrow 6 \\
\rightarrow 8 \rightarrow 4 \rightarrow 12 \rightarrow 11\end{array}$ & $21,19 \mathrm{~km}$ & $0,468 \mathrm{~s}$ \\
\hline $\begin{array}{l}\text { Rute } \\
\text { sekolah }\end{array}$ & $\begin{array}{l}8 \rightarrow 3 \rightarrow 6 \rightarrow 4 \rightarrow 13 \rightarrow \\
7 \rightarrow 10 \rightarrow 2 \rightarrow 9 \rightarrow 12 \rightarrow \\
5 \rightarrow 1 \rightarrow 14 \rightarrow 11\end{array}$ & $28 \mathrm{~km}$ & $0,566 \mathrm{~s}$ \\
\hline
\end{tabular}

TABEL VI

PERBANDingan ACS DAN PSO DALAM PENYELESAIAN Kasus

\begin{tabular}{|c|c|c|c|c|}
\hline \multirow{2}{*}{ Kinerja Uji } & \multirow{2}{*}{ ACS } & Standar & $\begin{array}{c}\text { Hybrid } \\
\text { Mutasi }\end{array}$ & Paralel \\
\cline { 3 - 5 } & & 19,83 & 16,96 & 20,63 \\
\hline $\begin{array}{c}\text { Titik } \\
\text { konvergensi }\end{array}$ & 63,4 & $0,046 \mathrm{~s}$ & $0,109 \mathrm{~s}$ & $0,093 \mathrm{~s}$ \\
\hline $\begin{array}{c}\text { Waktu } \\
\text { komputasi }\end{array}$ & $0,268 \mathrm{~s}$ & 0,0 & \\
\hline
\end{tabular}

nilai titik konvergensi. Hal ini menunjukkan bahwa ACS tidak terjebak pada konvergensi dini. Hal ini menyebabkan ACS dapat menemukan solusi global saat penyelesaian kasusnya. Pengujian kinerja ACS kemudian ditinjau dari waktu komputasi yang dibutuhkan. Hasil penyelesaian optimasi rute asymmetric city tour menggunakan ACS, berupa jarak tempuh dan waktu komputasi, untuk tiga kasus ini diperlihatkan pada Tabel V.

Tabel V menunjukkan waktu yang dibutuhkan algoritme untuk mendapatkan solusi yang optimum. Namun, jika dilihat dari seluruh hasil pengujian yang dilakukan, waktu yang dibutuhkan algoritme untuk mendapatkan solusi adalah $0,3739513<t<2,679453$. Hal ini dirasa cukup baik karena waktu komputasi ini relatif cepat dan memberikan hasil yang optimum.

\section{Hasil Perbandingan Metode ACS dalam Penyelesaian ATSP}

Selanjutnya, untuk mengetahui keandalan ACS dalam penyelesaian penentuan rute city tour, perlu dilakukan perbandingan dengan metode yang lain. Penelitian tentang optimasi rute city tour untuk studi kasus taman kota di Kediri juga pernah dilakukan [12]. Dalam penelitian tersebut, optimasi dilakukan menggunakan metode PSO dengan mengombinasikan operator mutasi dan membagi swarm menjadi dua subswarm. Hasil perbandingan dari optimasi tersebut dengan metode ACS ditunjukkan pada Tabel VI.

Tabel VI menunjukkan perbandingan kinerja ACS dan PSO dari segi titik konvergensi dan waktu komputasi. Hasil penentuan rute tidak ditampilkan karena menghasilkan nilai yang sama. Sedangkan dari sisi konvergensi swarm, ACS memiliki keunggulan dibandingkan dengan PSO standar maupun yang telah dimodifikasi karena dari hasil tersebut 
terlihat bahwa ACS tidak terjebak pada premature convergence seperti halnya PSO. Akan tetapi, karena ACS tidak terjebak pada premature convergence, maka algoritme ini membutuhkan waktu komputasi yang lebih besar dibandingkan PSO. Lebih lanjut, pengujian lebih dalam perlu dilakukan, karena nilai ini hanya diambil dari sebuah studi kasus dengan dimensi kecil. Oleh karena itu, studi lanjut dalam pengambilan kesimpulan ini sangat diperlukan.

\section{KESIMPULAN}

Model TSP standar tidak dapat diimplementasikan pada penentuan city tour karena jarak antar lokasi mungkin berbeda. Oleh karena itu, pada makalah ini city tour diselesaikan menggunakan konsep ATSP. Selanjutnya, algoritme ACS diimplementasikan dalam penyelesaian masalah ini. Kasus yang diselesaikan adalah lokasi pusat pariwisata, pusat industri, dan pusat pendidikan di Kota Kediri. Hasil yang diperoleh adalah ACS mampu memberikan solusi rute tur yang optimum dan lebih efektif, yakni rute tempat wisata kota $34,65 \mathrm{~km}$, rute industri 21,19 km, dan rute sekolah $28 \mathrm{~km}$. Pengujian untuk kinerja yang baik oleh ACS juga ditunjukkan pada titik konvergensi yang tidak terjebak pada lokal optimum dan waktu komputasi yang cukup singkat.

Selanjutnya, penelitian ini belum diimplementasikan pada sebuah peranti. Mengingat studi kasus yang diambil sangatlah cocok untuk implementasi pada peranti lunak bergerak (aplikasi mobile), maka diharapkan penelitian ini dapat dikembangkan lebih lanjut pada peranti lunak bergerak berbasis Android maupun IOS.

\section{UCAPAN TERIMA KASIH}

Terima kasih disampaikan kepada Kementrian Riset, Teknologi, dan Pendidikan Tinggi atas dukungan yang diberikan hingga terselesaikannya Penelitian Kerjasama Antar Perguruan Tinggi 2019 ini.

\section{REFERENSI}

[1] A. Chusna (2017) ANTARA News Jawa Timur. [Online], https://jatim.antaranews.com/berita/245508/kediri-dapat-penghargaankota-cerdas-2017-dari-wapres-jusuf-kalla, tanggal akses: 28-Nov-2019.
[2] M.D.A.C. Hasibuan dan Lusiana, "Pencarian Rute Terbaik pada Travelling Salesman Problem (TSP) Menggunakan Algoritma Genetika pada Dinas Kebersihan dan Pertamanan Kota Pekanbaru,” Jurnal SATIN - Sains dan Teknologi Informasi, Vol. 1, No. 1, hal. 35-46, Jun. 2015.

[3] F. Glover, G. Gutin, A. Yeo, dan A. Zverovich, "Construction Heuristics for The Asymmetric TSP,” European Journal of Operational Research, Vol. 129, No. 3, hal. 555-568, Mar. 2001.

[4] I.K. Gupta, S. Shakil, dan S. Shakil, “A Hybrid GA-PSO Algorithm to Solve Traveling Salesman Problem,” Computational Intelligence: Theories, Applications and Future Directions, Vol. 798, hal. 453-462, Agustus 2018.

[5] X.H. Zhi, X.L. Xing, Q.X. Wang, L.H. Zhang, X.W. Yang, C.G. Zhou, dan Y.C. Liang, “A Discrete PSO Method for Generalized TSP Problem," Proc. International Conference on Machine Learning and Cybernetics, 2004, hal. 2378-2383.

[6] N. Chandekar dan M.J. Pillai, "In a Comparative Study of GA and ACO for Solving Travelling Salesman Problem," International Journal of Mechanical and Production Engineering, Vol. 5, No. 11, hal. 34-37, Nov. 2017.

[7] A.A. Ismail dan S. Herdjunanto, "Penerapan Algoritma Ant System dalam Menemukan Jalur Optimal pada Traveling Salesman Problem (TSP) dengan Kekangan Kondisi Jalan,” JNTETI, Vol. 1, No. 3, hal. 4348, Nov. 2012

[8] A. Bajpai dan R. Yadav, "Ant Colony Optimization (ACO) for the Traveling Salesman Problem (TSP) Using Partitioning,” International Journal of Scientific \& Technology Research, Vol. 4, No. 9, hal. 376-381, Sep. 2015.

[9] B. Freisleben dan P. Merz, "Genetic Local Search Algorithm for Solving Symmetric and Asymmetric Traveling Salesman Problems,” Proc. IEEE Conference on Evolutionary Computation, 1996, hal. 616-621.

[10] A. Maria, E.Y. Sinaga, dan M.H. Iwo, "Penyelesaian Masalah Travelling Salesman Problem Menggunakan Ant Colony Optimization (ACO)”, Jurnal Media Informatika, Vol. 6, hal. 1-5, 2008.

[11] X. Chen, Y. Zhou, Z. Tang, dan Q. Luo, “A Hybrid Algorithm Combining Glowworm Swarm Optimization and Complete 2-Opt Algorithm for Spherical Travelling Salesman Problems,” Applied Soft Computing Journal, Vol. 58, hal. 104-114, September 2017.

[12] A. Izzah, B.A. Nugroho, W.F. Mahmudy, F.A. Bachtiar, T.A. Cinderatama, dan Y.A. Sari, "Convergence Analysis in Swarm Intelligence for City Tour Optimization,” Proc. International Seminar on Research of Information Technology and Intelligent System, 2019, hal. 109. 